UDC 004; 159.9; 658

\title{
Oleksandr Burov
}

Doctor of Engineering, Leading Researcher

Institute of Information Technologies and Learning Tools of the NAES of Ukraine, Kyiv, Ukraine

ORCID ID 0000-0003-0733-1120

ayb@iitlt.gov.ua

\section{Oleksandr Butnik-Siversky}

Doctor in Economics, Professor, Academician of the Academy of Technological Sciences of Ukraine, Chief Scientist

Scientific Research Institute of Intellectual Property of the NALSU, Kyiv, Ukraine

ORCID ID 0000-0003-2492-231X

busiv@ukr.net

\section{Olena Orliuk}

Doctor of Law, Professor, Academician of the National Academy of Law Sciences of Ukraine, Advisor to the Director Scientific Research Institute of Intellectual Property of the NALSU, Acting Director of the Institute of Law at Taras Shevchenko National University of Kyiv, Kyiv, Ukraine

ORCID ID 0000-0001-5145-5919

e.orliyk@ndiiv.org.ua

\section{Kateryna Horska}

Doctor in Social Communication

Institute of Journalism at Taras Shevchenko National University of Kyiv, Kyiv, Ukraine

ORCID ID 0000-0002-3430-6206

k_horska@univ.net.ua

\section{CYBERSECURITY AND INNOVATIVE DIGITAL EDUCATIONAL ENVIRONMENT}

\begin{abstract}
The article considers interaction of innovation, cybersecurity, and digital education environment. It has been demonstrated that comprehensive digitalization of society is being accompanied by changes in the innovative potential and educational needs of Ukraine, especially in the development of the human intellectual capital and its protection in the digital environment. Human capital in innovation plays a significant role, especially in the digital age. Young people are considered as a vulnerable group that could be the main goal of cyber cognitive operations and as the weakest link of the System. The analysis of the Global Innovation Report has revealed that the real level of digitalization in Ukraine does not match its actual human potential and creative outputs. Ukraine has faced gaps in the triangle "human capital (potential) - technological support of innovations - creative activity" that should be eliminated to increase the national Global Innovation Index (GII). Human talent and competence (as a capital) are developed in the learning process.

It has been noted that a joint project is the weakest link in terms of intellectual capital and the intellectual property right. Personal information about the project competitors is usually not defended. The issues of innovation in the digital learning environment exacerbate the issues of cybersafety of the education process participants. The traditional cybersecurity approach is unable to detect and tackle new sophisticated attacks. The authors have developed a general model of cyber threats in the field of education and mitigation of their impact.The new strategy in cybersecurity is proposed: not only prompt defence, but threat hunting and resilience training of users. Threat hunting can be presented by two approaches: threat detection (reactive) and threat discovery (proactive), as components of the proposed model. The resilience training of users is associated with threat awareness and special cybersafety training. A general model of cyber threats in the field of education and ways to avoid them is presented.

Special attention should be paid to the strengthening of the role of media in educational processes in digital environment, as a current area of cyber hazards. The role of media in stimulating horizontal communication in the educational process is growing. Participants in the digital environment are confidently turning from passive consumers to prosumers, and the media are becoming an information intermediary with a double function: a platform for providing access
\end{abstract}


and information exchange in the educational process and technological tools for joint creation of products (creative commons).

Keywords: ICT; innovation; digital information environment; media; intellectual property; cyber-safety.

\section{INTRODUCTION}

It is known that development of digital technologies is accompanied by the innovation and intellectual property support in the process of accelerating the transformation of society, growth of the share of intangible objects production (information, knowledge) and, accordingly, the growth of the role of human capital and its place in history. The goal of innovation in the Forth Industrial Revolution has been formulated in the WIPO 2019 report as "taking the pulse of innovation expenditures and policies around the world" [1, p.2]. It aims to continue and specify previous directions of development, stated in the WIPO 2014 report as being of a particular importance: accelerating the development of information and communication technology (ICT) and society, innovation and the human factor, education in the structure of the human factor, intellectual property and human capital. "Applying learning science insights to ICT education, educators can create a dynamic, digital, and hands-on learning experience that is tailored, flexible, and relevant, developing the talent needed to power the digital economy" $[2, \mathrm{p} .8]$.

At the same time, experts noted that "as we embark on the Fourth Industrial Revolution, it's clear that technology will play a central role in nearly all aspects of our lives. Research by the World Economic Forum estimates that $65 \%$ of children entering primary school will find themselves in occupations that today do not exist. In 2020 it's estimated there will be 1.5 million new digitized jobs across the globe. At the same time, $90 \%$ of organizations currently have an IT skills shortage, while $75 \%$ of educators and students feel there is a gap in their ability to meet the skills needs of the IT workforce" [3, p.1]. And the time came to change the education paradigm from aiming to replicate past facts and knowledge to shifting learning content and experiences towards the needs of the future [4]. According to the concept of lifelong learning, appropriate tools and means should be innovative and valid for both learning and working environment [5], and they need protection as tools for creating intellectual capital and intellectual property in the digital world [6], because new obstacles pose risks to global innovation.

The problem statement. As COVID-19 pandemic "continues to disrupt global health, economic, political and social systems, there's another unseen threat rising in the digital space: the risk of cyber-attacks that prey on our increased reliance on digital tools and the uncertainty of the crisis" [7, p.1]. According to PurpleSec LLC, Cybercrime increased up $600 \%$ due to COVID-19 pandemic [8]. Malicious agents are posing as the Center for Disease Control and Prevention or World Health Organization (WHO) representatives, or act via the U.S. Federal Pandemic Unemployment Assistance, exploiting people's need for information about the coronavirus situation and the labour market. In view of the cautiously pessimistic projections of WHO for the counteringCOVID-19, cyber-attacks in these areas can be expected to intensify [9].

The information revolution and globalisation change world economics and politics. At the same time, "in a world where borders are becoming more porous to everything from illicit drugs and infectious diseases to terrorism, countries must use their soft power of attraction to develop networks and build regimes and institutions to address these new security threats" [10, p.2]. Richard Danzig highlighted: "Twenty-first century technologies are global not just in their distribution, but also in their consequences. Pathogens, AI systems, computer viruses, and radiation that others may accidentally release could become as much our problem as 
theirs" [11, p. 2]. Especially, this can affect a human life because of unexpected and extremely fast transition to distance education globally, and necessity to change education forms and technologies [12].

Analysis of recent studies and publications. As it was noted above, the global market needs extended workforce with ICT skills [3] and innovations. According to the Derwent Top 100 Global Innovators 2020 and Clarivate Analytics new report, innovative activity has increased in recent years, and not only in 1000 leading companies [13]. Moreover, results of analysis demonstrated three key trends in the market: (1)reduction of the share of innovations of 1000 leading companies in the total volume of inventions (their share was $27 \%$ of inventions six years ago, 18\% today), (2) the need for cooperation (inventions become more knowledge-intensive and require the participation of a wide variety of specialists and researchers), (3) increasing the threshold for entering the list of Top100 (the number of patent applications required to enter the Top100 has grown by $22 \%$ over the past 6 years). The successful newcomers to the 2020 roster (Fujikura, HTC, Immersion, Microchip, Schneider Electric and Tencent) have grown by an average of 250 spots since 2015 [14].

The situation is aggravated by the fact that education has changed dramatically, with the distinctive rise of e-learning, whereby teaching is undertaken remotely and on digital platforms [15, p.2]. Research suggests that online learning increases efficiency of learning and retention of information [16], and takes less time, meaning the changes the coronavirus has caused might be here to stay [17]. We believe that online learning can be the catalyst to create a new, more effective method of educating students based on innovative technologies [18] and network tools [19].

As Carlos J. Ochoa, the Co-Chairof VR/AR Association's Education Committee, highlights, "education is the driver to sustainability of our economy and functionality of humanity. Educating the individual is the country's most valuable investment... Through virtual and augmented realities, the technology allows the user to immerse themselves into a virtual experience or location and the immersive lesson is retained at a much quicker time frame with a more impactful lasting memory" [20, p.2]. VR \& Learning scores a retention rate of $75 \%$, which increases the learning efficiency, and the learning process can be easier adapted to the individuals' abilities. "Understanding we are moving into a world with exponential growth, there is a necessary requirement to update our education system to support innovative technologies to understand how it will be applied to job creation and support digital support systems and processes" [20]. Global changes in 2020 need to take action and implement new tools in the education system, because traditional methodologies and tools fail to provide rapid solutions to the society needs.

At the same time, humanity faced risks related to the safety and security of the digital environment, because conventional wars have moved to the digital world as well. "Survivability is the ability of a system, subsystem, equipment, process, or procedure to function continually during and after a disturbance. This must be the focus of our attention as the digital battlespace continues to be transited" [https://cdn.ttgtmedia.com/rms/pdf/CyberWarfare_ch10.pdf, p.28], and cybersecurity at the state and corporate levels has to be extended into the field of human factors more actively [21].

The article's goal is to analyze trends in transition to the comprehensive digitalization of society, as well as accompanying changes in the innovative potential and educational needs of Ukraine, including development of the human intellectual capital and its protection in the digital environment. 


\section{THE THEORETICAL BACKGROUNDS}

The development is a way of obtaining the necessary strategic resources for life - space, energy, time and information. Accordingly, the value of each of these strategic resources differed in different technological contexts. Because local (spatial) resources are limited by population growth and increased activity, there are two possibilities for a country to survive: 1) the fight against competitors for local resources, 2) the acceleration of development to obtain additional resources beyond the locality. The faster one develops, that is, adopts new technologies, the more likely it is to "capture" external resources.

The specificity of the information age and the global use of ICTs is that the product of human activity (information, formalized knowledge) can enter the information environment (global networks) and remain there infinitely long unlike material-object products, the life cycle duration of which is limited by the lifetime of the material substance. The transition to the VI technology paradigm means a significant increase in resources "time" and "information", because the "space" in the information environment is relatively meaningless, expanding to the space of planetary global networks. Accordingly, priorities in innovation are shifting towards the struggle for the gain of time and information (knowledge), which is directly related to the action of the human factor. Capitalization of human assets is conditioned not only by knowledge, experience and motivation, but also by psychophysiological compliance with the requirements of work, information and communication capabilities; human assets acquire the features of the most valuable and financially attractive investment object; intelligence becomes capital, and its media are financed more and more intensively as a pro-active way to avoid increasing global risks [12].

As a result, to date, the most innovative companies work in the area of electronics and information and communication technologies. According to the Boston Consulting Group list of Top50 most innovative companies in the world (as of 29.06.2020), the first 6 in rating are Apple, Alphabet (with its search tool Google), Amazon, Microsoft, Samsung and Huawei, i.e. world leaders in ICT [22].All of them develop teaching tools and pay significant attention to the embodied cybersecurity support. However, it should be noted that their innovations deal with the technical and informational aspects, not prompt human factor. Nevertheless, the latter is in a focus of their activity, so "soft" aspects of related application are developed by other stakeholders, considering other aspects of cybersecurity [21].

Our approach is based on the possible impact of digital space on human, as well as human-related directions in cyber-security analysis in education: levels of cyber-security, social engineering role, "cognitive vaccination". Young people are considered as a vulnerable group that could be the main goal of cyber cognitive operations in long-term perspective, and as the weakest link of the System [23]. Cybersafety of participants in the educational process must include such types of protection as legal, technical, informational, organizational, and psychological [23, p.361]. All of these types are accompanied by innovations and need cybersecurity and cybersafety solutions to be embodied.

\section{THE RESULTS AND DISCUSSION}

Actual tasks of creation of innovative human capital development technologies for digital environment can be represented by a wide spectrum of aspects. They are discussed in this article in the following domains: 1) innovative potential of Ukraine; 2) innovation and digitalization in education; 3 ) cybersafety in education. 


\subsection{Innovative potential of Ukraine}

The model of the technology and human activity transformation allows understanding differences in previous technology paradigms (I ... V) and current $\mathrm{VI}^{\text {th }}$ (nano-, bio-, cogniand info-) one [12]. It is recognized that cognitive technologies and biological knowledge related to a human create a new expanded basis of the human being when using ICTs and transitioning to the digital environment, where ideas, knowledge and a human talent become the innovative capital.

In general, the human capital as a part of the intellectual capital is a significant component in the structure of an innovation indicator, and on the other hand, it is directly related to the concept of "human factor". The WIPO report analyzed the link between innovation and the human factor explored in WIPO's Global Innovation Index [2]. It was highlighted that ideas, know-how, innovative and enterprising people regularly crossed borders and created value locally and globally; the projects brought together people from different continents, who lived outside their countries of origin. The engine of that global and mobile world was talent enforced by developing ICTs.

From the theoretical point of view, the problem of assessing the level of innovation of new developments is analyzed by the authors in the following aspects: economic, organizational, financial, legal, informational, and technological. Special attention should be paid to the intellectual property in education and creative processes where people communicate using ICTs and networks.

The structure of innovation performance indicators is represented by a tree with two branches (sub-indexes): innovation costs (allows evaluating the elements of the national economy in which innovation activity is implemented) and innovation results (reflects the actual results of innovation activity) (Fig.1).

The second sub-index consists of: knowledge and use of ICT outcomes (knowledge creation, knowledge impact, and knowledge penetration), results in creativity (intangible assets, creative goods and services, online creativity).

Special attention is paid to the problem of the disappearance of the localization of educational (as well as any other) information, the erasure of its borders, its existence with almost no time limit, and, accordingly, the emergence of a balance of rights and responsibilities of authors for that knowledge that becomes the property of mankind and influences business processes [2].

Global changes in innovation area over the last five years clearly demonstrated that [1]:

$\checkmark$ despite economic slowdown, innovation is progressing around the world; but new obstacles pose risks to global innovation;

$\checkmark$ shifts in the global innovation landscape are materializing; some middle-income economies are on the rise;

$\checkmark$ innovation inputs and outputs are still concentrated in very few economies; a global innovation divide persists;

$\checkmark$ some economies get more return on their innovation investments than others;

$\checkmark$ shifting focus from innovation quantity to innovation quality remains a priority;

$\checkmark$ most top science and technology clusters are in the U.S., China, Germany, Brazil, India, Iran, the Russian Federation, and Turkey. They pay high attention to the development and use of ICTs in all fields of life and activity.

These "strong innovators" demonstrate the increasing levels of innovation performance due to the improvement of the regulatory framework for innovation activity, the availability of skilled workforce with advanced higher education. 


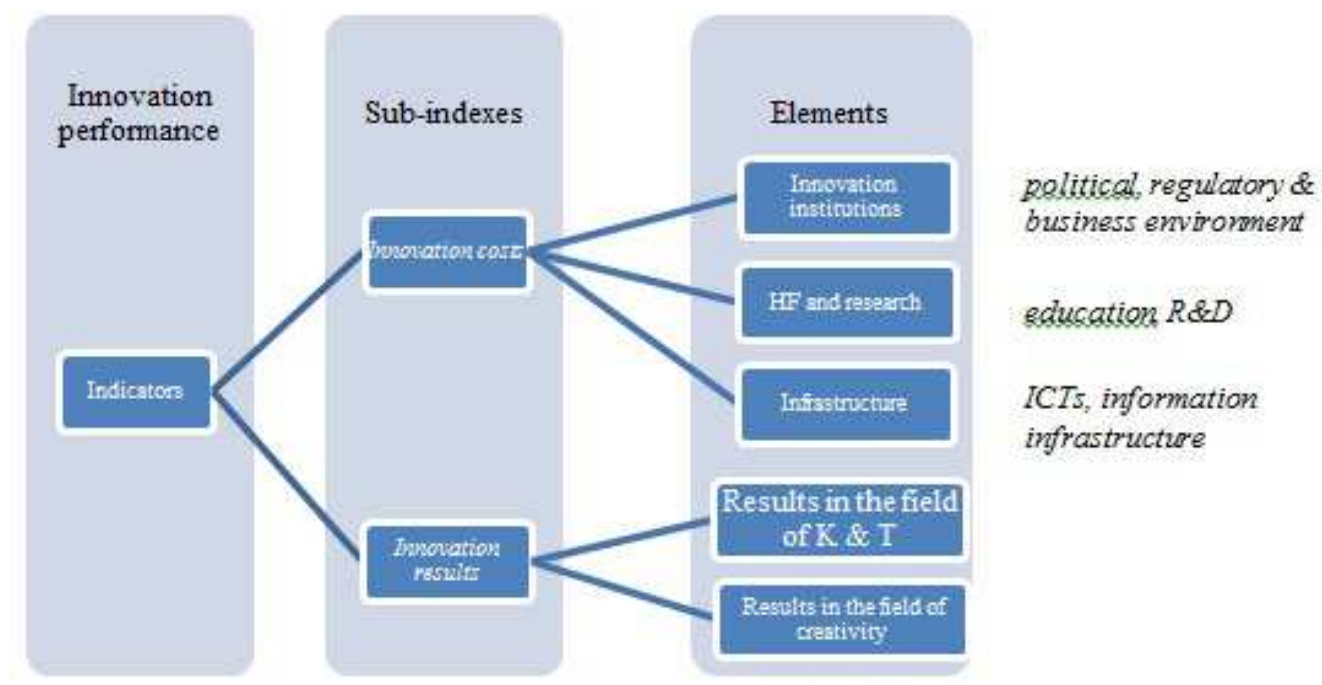

Fig. 1. The structure of innovation performance indicators in ICTs

The reports [1; 2] emphasize that human innovation is one of the reasons why innovation leaders remain at the top of the rankings and why some of the large emerging market countries have different indicators of innovation. At the same time, it is necessary to highlight that the unevenness of innovative development is largely determined by the imbalance of state influence on the education and development of science and the human potential of the country. According to the Global Innovation Index 2019, Ukraine is in the Top 3 innovation economies by income group with lower-middle income, and it ranks 47th among the 129 economies featured in the GII 2019 [1]. Ukraine performs better in Innovation Outputs (36th) than Inputs (82nd). More detailed analysis of main 7 GII pillars clearly demonstrated that Ukraine has a great potential to improve its GII (Fig.2).

Ukraine ranks quite high in:

$\checkmark \quad$ Knowledge \& Technology Outputs (rank 28) including Knowledge creation (Utility models by origin/bn PPP\$ GDP, 1st rank; Patents by origin/bn PPP\$ GDP, 17th rank), Knowledge impact (Computer software spending, \% GDP, 19th) and Knowledge diffusion (ICT services exports, \% total trade, 11 th);

$\checkmark$ Creative Outputs (rank 42) including Intangible assets (Trademarks by origin/bn PPP\$ GDP, 6th; Industrial designs by origin/bn PPP\$ GDP, 8th), Online creativity (Mobile app creation/bn PPP\$ GDP, 19th), but low Creative goods \& services (average rank is 91).

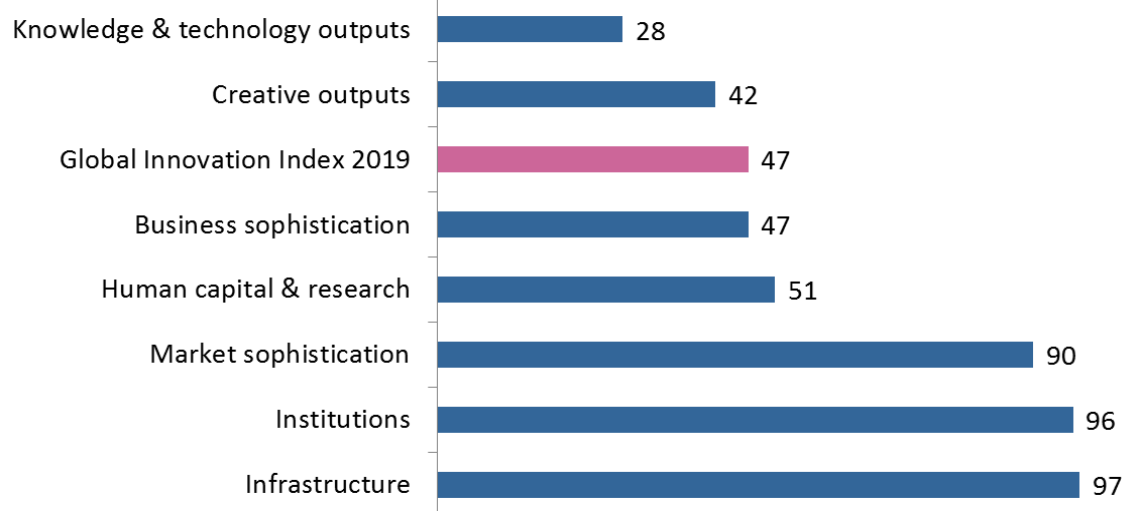

Fig. 2. Ukraine's rankings in the 7 GII areas (according to [1, p.388]) 
These results indicate that there are qualified creative people experienced in innovation in Ukraine. But, at the same time, Human Capital \& Research as the GII pillar is not high (51st rank). Moreover, Education has 43rd rank (though Pupil-teacher ratio, secondary, is 3rd), Tertiary Education has 37th (Tertiary enrolment, \% gross, 14th, but the indicator "Graduates in science \& engineering, \%", is $33^{\text {rd }}$ by rank) and Research \& Development $(R \& D)$ is 54th with low component of expenditure on R\&D, (67th). In other words, Ukraine's human capital is competitive with countries from the high-income group, but low funding of the R\&D restrains intellectual development potential despite young people's interest in higher education.

Unfortunately, the real level of digitalization in Ukraine does not match its actual human potential and creative outputs. Particularly, Infrastructure pillar in general (97th) and even Information \& communication technologies (ICTs) as sub-pillar (81st) do not meet requirements of today's global trends. So, we can say that Ukraine has faced gaps in the triangle "human capital (potential) - technological support of innovations - creative activity" that should be eliminated to increase the national GII.

The useful view to solve this task can be taking into account experience and solutions provided by the discipline Ergonomics/Human Factors (HF/E). Especially it is reasonable to look at it from the point of view of the digital environment and information ergonomics as an appropriate approach inside this discipline that is developing in relation to human activity and innovative tools, technologies and organizational support in the context of the human-system integration. Special attention should be paid to the use of media tools to change people's attitude to information, ICTs, knowledge, and education in the digital age [29].

\subsection{Innovations in education needed}

The authors agree with the viewpoint of Suphachai Chearavanont, Chief Executive Officer, CP Group, The World Economic Forum COVID Action Platform, that the digitization and innovation have great potential for society to mitigate important issues, including public health, education and our environment. There are a lot of discussions related to distance education, pro\&contra. The main topic is "This form was not effective, because many children lost opportunities for learning". But we strongly believe that it is necessary to distinguish criteria of analysis:

(1) Availability of distance learning tools. E.g., the classroom form of learning could be the only form in economically poor countries or regions, and education in this case needs social and financial solutions, first of all.

(2) Digital literacy of students and teachers, which turned out to be insufficient for the unexpectedly emerging new conditions.

(3) Even for those who can access distance learning, success depends on their living conditions, including the fair distribution of domestic duties.

(4) Even the availability of technical tools turned out to be insufficient in the conditions of a total transition to distance learning, because it required changes in technologies of mass education.

(5) Social and motivational gap: lack of prompt impact of a teacher on a student decreased motivation of those students who have not developed self-motivation and interest in learning.

Criteria (1)...(4) are global and António Guterres, the Secretary-General of the United Nations, highlighted that more than 250 million school-age children were out of school during the pandemic, "schools were closed in more than 160 countries, affecting over 1 billion students. At least 40 million children worldwide have missed out on education in their critical pre-school year" [17]. Nevertheless, he stated: "We can take a leap towards forward-looking 
systems that deliver quality education for all as a springboard for the Sustainable Development Goals". To achieve this, "we need investment in digital literacy and infrastructure, an evolution towards learning how to learn, a rejuvenation of life-long learning and strengthened links between formal and non-formal education. And we need to draw on flexible delivery methods, digital technologies and modernized curricula while ensuring sustained support for teachers and communities" [17].The implementation of ICT in education will be a starting point of a society that still does not comply with the dynamism of adaptation actually needed. It demonstrates the integration of ICTs into education, when the educational system can design meaningful learning, the product of experiential experiences and reflective content, secure the achievement of generating knowledge in students and teachers. It does not focus only on the classroom where learning is evidenced, it must postulate the idea of becoming this achievement of significance. ICTs, as technological tools, have increased the degree of significance and educational conception, establishing new communication models, in addition to generating spaces for training, information, debate, reflection, among others; breaking with the barriers of traditionalism, in the classroom [24, p.333].

The education processes at all stages of the educational system have undergone great changes at the methodological, didactic, and pedagogical level, mainly as a result of the expansion of educational technology [25]. A lot of technological resources are now accessible for students, society has become digitalized and the "school" must assume and integrate those socio-educational needs into the human training. The knowledge and information society offers many possibilities (from immersion to the promotion of educational processes in an innovative way). "They also facilitate access to educational resources, materials and multimedia tools and allow the creation of contents even in a personalized way" [25]. Therefore, the innovative technological tools have a clear objective: to provide flexibility and adaptation to the needs of each student within the new educational scenario, to create the intellectual capital of the country.

The term "intellectual capital" is widely used in international practice, and is adapted to the system of modern business taking into account the needs of intellectual property valuation and is considered as knowledge, resources used, economic product, and the basis of the organization to carry out economic activities [26, p. 8]. Under such conditions, an attempt to capitalize on knowledge created as a result of human intellectual activity becomes widespread. Human capital is considered as capital formed and developed as a result of investment and achievement by people with a certain level of health, knowledge, skills, abilities, motivations, which are purposefully used in a particular area of social production. In the traditional sense, human capital cannot be outside production, where intellectual capital is born, the creators of which are high-class specialists. And education/training of such high-class specialists should be a goal and the main condition of society that will promote the development of workforce professional competences and intellectual capital.

We share the viewpoint of other researchers that appropriate indicators can be proposed for some specific cases of individual competencies: (1)growth and renovation (experience, educational level, training costs, personnel rotation etc.); (2)efficiency (proportion of professionals, value added by professionals);(3)stability (average age, length of service, rotation of professionals etc.).

Transformation of education across the globe aims to use project-oriented approach with practical skills based on innovative technologies and tools. One can expect the creation and intensive use of virtual/augmented/mixed reality means as well as artificial intellect in the synthetic learning environment [18]. At the same time, such an activity gives a learner an opportunity to create new ideas, goods, practical applications and gain experience, i.e., to realize his/her "human intellectual potential as the available amount of knowledge, 
qualification, the ability to work creatively, which he/she has got in previous periods of the life, to engage in an innovative production or trade process and provide innovative services" [26, p. 38]. The results of creative work in the form of an intellectual product, which has no value, but is measured by the number of identified objects of intellectual property rights, are characterized by intellectual resources.

But it should be noted that a joint project, especially realized in the digital network, becomes the weakest link in terms of intellectual capital and the intellectual property right, because requirements for such projects become increasingly higher in relation to novelty, on the one hand, and the project is not protected by law, being available to third parties who are not the authors, on the other. Besides, personal information about the project competitors is usually not protected either. Thus, the issues of innovation in the digital learning environment emphasize the issues of cybersafety of participants of the education process.

\subsection{Cybersecurity in education}

The COVID-19 pandemic poses the risk of increased cyberattacks. Hackers are targeting people's increased dependence on digital tools. Strategies to maintain cybersecurity include maintaining good cyber hygiene, verifying sources and staying up to date on official updates. "In a pandemic of this scale - with cases of coronavirus reported in more than 150 countries - dependency on digital communications multiplies. The Internet has almost instantly become the channel for effective human interaction and the primary way we work, contact and support one another" [7, p.1]. Emergent transfer to remote work and education worldwide has massively amplified the problem of protecting proprietary information. As companies and educational institutions had to implement remote access technologies, they often could not secure their workspace, making participants of the working process open for vulnerability. This led to the frequent neglect of even the most basic security and compliance protocols. According to experts, there are three reasons robust cybersecurity measures matter more than ever: a heightened dependency on digital infrastructure raises the cost of failure, cybercrime exploits fear and uncertainty, more time online could lead to riskier behavior.

The Forth [3] and, especially, Fifth Industrial Revolutions require including of economic knowledge and skills into the general competences [10]. According to the viewpoint of Seán Doyle, Project Lead, Industry Solutions, Centre for Cybersecurity, World Economic Forum, changes evoked by the pandemic have exacerbated the problems:

$\checkmark$ Financial Technology (FinTech) providers are key elements to the structural enhancement of financial services during the Great Reset.

$\checkmark$ Cybersecurity is critical to ensuring consumers and businesses can leverage the benefits of FinTech and bounce back from the crisis.

$\checkmark$ The World Economic Forum's FinTech Cybersecurity Consortium released recommendations for a common approach to cybersecurity controls.

And not only financial area can be vulnerable to hackers. Malware can be deployed on any endpoint. A human cognitive sphere in general became the target for attackers, and a learner's knowledge, way of thinking, critical abilities and life value system can be breached through wrong (replaced) content, false links when searching information in the network, fake news, interferences during teaching/learning communication, demotivating external influence on participants of the learning process etc., because distributed creation and storage of information is a door half open, remote learners are easy targets, and distributed setups complicate security breach discovery and counterattacks. Besides, artificial intellect (AI) is used more actively not only by cybersecurity personnel and hackers, and it is important for big data analysis. 
As noted by the participants of the World Economic Forum 2020, "the first chapter of the Fourth Industrial Revolution has been powered by an explosion of data harnessed by extraordinary advances in technology and the spread of connected devices. As a result, seven technology companies are now among the eight most highly valued companies in the world. The success of the next chapter in the world's digital transformation depends on governments and companies ensuring data is used in a way that balances benefits across the broader economy and society as a whole" [27]. Today, the transformative technologies underpin modern civilization and will help drive solutions to the new digital frontier that is based on a single resource - data - and is underpinned by constant connectivity and the disruptive power of computing.

New (innovative) digital technologies are literally undermining traditional approaches to automation of production and business. This presupposes that AI becomes a significant contribution to the economic growth of any state, as well as social development. The WIPO Technology Trends 2019 of Artificial Intelligence study provides documentary evidence that the number of AI-based inventions has increased dramatically recently. Many experts recognize three category of AI: Artificial Narrow Intelligence (specialized in one field), Artificial General Intelligence (the 2nd level) and Artificial Super Intelligence (the $3 \mathrm{~d}$ level). The ratio of scientific publications and patent families of AI decreased from 8:1 in 2010 to 2:1 in 2020, which indicates the transition from theoretical research to practical implementation [28, p.89].At the same time, implementation of AI is accompanied by the new trend: companies now face sophisticated enemies using AI and machine learning tools for their attacks. This is a world of new threats for those defending network systems and data.

Another innovative technological trend in education deals with active implementation of $\mathrm{AR} / \mathrm{VR} / \mathrm{XR}$. Learning is becoming more interactive, more fun, more immersive and more social, specifically, in the direction where new advanced technologies and methodologies will improve learning and teaching process with the aim of "placing students in any real world or virtual situation with an active role in proceedings through various tasks they will need to complete. Situations and outcomes will dynamically change depending on the inputs and this will keep the student active and engaged throughout the lesson"[20]. Different students with classroom experiences gain varying levels of presence (music, arts, dance, painting, performing itself) in creative immersive environment.

More and more facts pointed out that the traditional cybersecurity approach is unable to detect and tackle new sophisticated attacks such as the advanced persistent threat (APT), and such a situation is developing in time. The new strategy in cybersecurity can be effective: not only prompt defense, but threat hunting and resilience training of users.

Threat hunting can be presented by two approaches: threat detection (reactive, currently used and has been developed in both theoretical and practical aspects) and threat discovery (proactive, that includes retrospective discovery, artifact discovery and activity discovery).

The resilience training of users is associated with threat awareness and special Cybersafety training [27].

The general model of cyber threats in the field of education and approaches to avoid them is presented in Fig.3. 


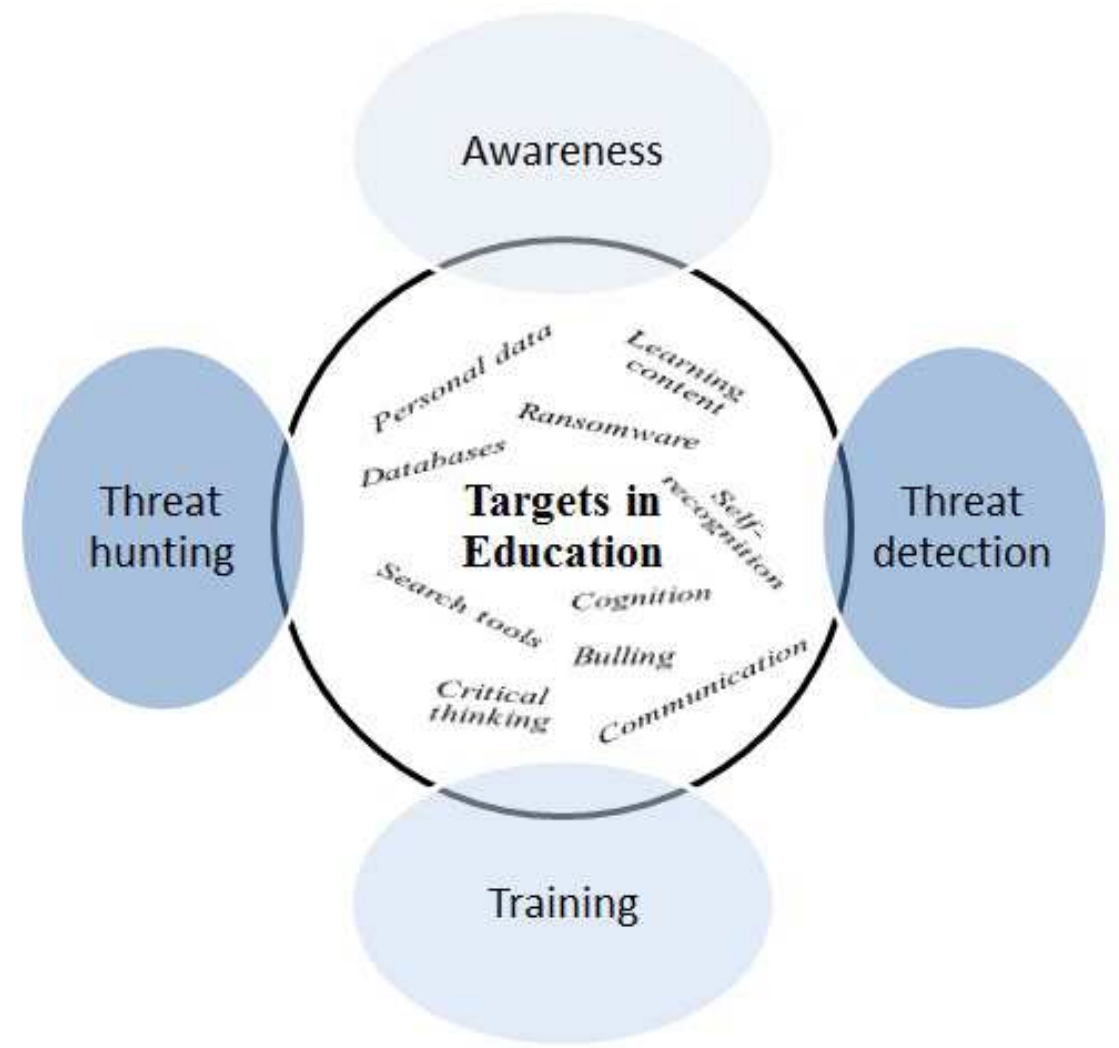

Fig. 3. The general model of cyber threats in the field of education and mitigating their impact

Special attention should be paid to the increasing role of mass-media and social networks in remote education with accompanying cybersecurity challenges.

\subsection{Social and humanitarian aspects of cybersecurity}

We strongly believe that more attention should be paid to the strengthening of the role of media (in its broadest sense - news production, entertainment industry, film production and visual arts) in educational processes, first of all, in digital environment.

Calls for limiting "screen time" for young people today have been cancelled in the face of the COVID-19 pandemic. On the contrary, the transition to online learning has become the impetus for the rapid growth in the scale of digital participation, primarily on the part of the younger generation. According to UNESCO data, the number of students (at all levels from preschool to higher education) forced to limit or transfer their education to distance learning is more than 1 billion in more than 150 countries worldwide, which makes us take the problem of educational policy in the media environment more than seriously.

The possibilities of digital media technologies are impressive in their diversity, which naturally leads to their active involvement in educational processes. This is also evidenced by the increased popularity of such content formats as the explainer.

At the same time, the alternative media space, replete with information, becomes essentially an autonomous self-sufficient environment that actively participates in learning, personality formation, and the establishment of social ties that replace educational and social institutions. Moreover, the unsystematic nature of the information supplied, to which sceptics appeal, and the potential for learning through the media environment, in fact, form a system of priorities for each single individual based on his/her identified interests. Such an algorithmically inherent "indulgence of the user" gives rise to the Filter bubble phenomenon, 
which is undoubtedly dangerous for young people who are not sufficiently knowledgeable in matters of media literacy and critical assessment of sources.

It should be noted that the majority of media resources find access to their audience mainly through a search monopolist, whose colossal influence on the information space, politics and social reality as a whole has long been called "googlearchy". In reality, multiple information sources are passed through the "filtering ring"of the search engine with its predetermined selection algorithms, which threatens freedom of choice and access to information [29].

According to The Common Sense Census: Media Use by Tweens and Teens, 2019, the media industry is the leader in producing engaging content for a young audience. Today, adolescents' consumer priorities regarding content and distribution channels are centered around video formats, social content, consumption from mobile devices, and this trend has only intensified over the past few years. This gives us reason to assert that the role of the media as a key source not only for receiving information (from news to entertainment), but also social identification in general, will continue to grow. The media, which have survived the challenges of aggregation and the subjectivity of blogging practices, today, according to experts, should return to fulfilling the social function of education, which is more relevant than ever in the light of current trends, responsible and critical behaviour of citizens not only as consumers, but also as communicators and producers of media messages. At the same time, the media environment, due to its growing influence and dynamic implementation of technologies, also requires urgent decisions regarding regulation and increasing the level of media literacy [29].

Nowadays, more and more people are talking about the new media's watchdog role as an important condition for the formation of a "socially healthy" media environment. However, the peculiarities of personalized information consumption by Gen Y \& Gen Z lead to the fact that certain issues and content (including educational) play a big role in the lives of young people, making it both easy and difficult in terms of exposure to influence. Therefore, the media should be integrated as much as possible into the educational environment, rather than follow only their own path. Considering media both as content and a platform, many experts refer to Remote Learning as mixed media learning, allowing both teachers and learners to interact with the content. It is not possible to solve the problem of interacting with verified content by just purchasing software and a mobile application. AI-powered applications which can design a customized curriculum for learners based on their level of knowledge and learning ability are not developing very rapidly. Chatbots can be used both to provide feedback to a student and to evaluate their validity with high accuracy without the participation of a teacher. However, it is too early to talk about the introduction of eTeachers practice.

In this context, as Yu. Krylova-Grek noted, cybersecurity cannot be viewed only as a set of security measures to preserve the confidentiality of information, since it involves communication-related activities. It is crucial to teach people to recognize and confront the techniques used by social engineers to get access to sensitive data and to improve their information security awareness [30, p.210]. Common methods of influence exploited by social engineers are aimed at governing the consciousness of the object of attack and his/her emotional-affective sphere, as well as blocking the processes of rational and critical thinking, manipulating person's moral and ethical attitudes.

\section{CONCLUSIONS AND PROSPECTS FOR FURTHER RESEARCH}

Human capital plays a significant role in innovation, especially in the digital age, because information becomes not only environment, but a tool of activity. Young people are 
considered as a vulnerable group that could be the main goal of cyber cognitive operations in long-term perspective, and as the weakest link of the System. Cybersafety of participants in the educational process must include such types of protection as legal, technical, informational, organizational, and psychological ones. All these types need innovations, cybersecurity and cybersafety solutions to be embodied.

The analysis of the WIPO Global Innovation Report has revealed that the real level of digitalization in Ukraine does not match actual human potential and creative outputs. Particularly, Infrastructure pillar in general and even Information \& Communication Technologies as sub-pillar do not meet requirements of today's global trends. Ukraine has faced gaps in the triangle "human capital (potential) - technological support of innovations creative activity" that should be eliminated to increase the national Global Innovative Index and the level of the human capital development.

It should be noted that a joint project, especially realized in the digital network, becomes the weakest link from the viewpoint of intellectual capital and the intellectual property right, because requirements for such projects become increasingly higher in relation to novelty. At the same time, the project is not protected by law, being available to third parties who are not its authors. Personal information about the project competitors is usually not defended either. Thus, the issues of innovation in the digital learning environment exacerbate the issues of cybersafety of the education process' participants.

It has been argued that more and more facts pointed out that the traditional cybersecurity approach is unable to detect and tackle new sophisticated attacks such as the advanced persistent threat, and such situation is developing in time. A new strategy in cybersecurity is proposed: not only prompt defense, but threat hunting and resilience training of users. The threat hunting can be presented by two approaches: threat detection (reactive, currently used, developed in both theoretical and practical aspects) and threat discovery (proactive, that includes retrospective, artifact, and activity discovery). The resilience training of users is associated with threats awareness and special cybersafety training. A general model of cyber threats in the field of education and approaches to avoid them has been developed.

The role of media in stimulating horizontal communication in the educational process is growing. Participants in the digital environment are confidently turning from passive consumers to prosumers, and the media are becoming an information intermediary with a double function: a platform for providing access and information exchange in the educational process and technological tools for, in particular, joint creation of products (the terms used are: creative commons, co-creative).

It has been demonstrated that comprehensive digitalization of society is accompanied by changes in the innovative potential and educational needs of Ukraine, especially in the development of the human intellectual capital and its protection in the digital environment. The further research is planned to be carried out with the focus on implementation of innovative tools, monitoring of new cyber threats, and development of the human capital, especially in the digital/synthetic learning environment.

\section{REFERENCES (TRANSLATED AND TRANSLITERATED)}

[1] Creating Healthy Lives - The Future of Medical Innovation. Key Findings. Cornell University, INSEAD, and WIPO, 2020. [Online]. Available: https://www.wipo.int/edocs/pubdocs/en/wipo_pub_gii_2019-intro3.pdf. Accessed on: 16.08.2020 (in English)

[2] The Global Innovation Index 2014: The Human Factor In innovation. Cornell University, INSEAD, and WIPO, Fontainebleau, Ithaca, and Geneva, 2014. Accessed on: http://www.wipo.int/econ_stat/ru/economics/gii. 428 p. Accessed on: 16.08.2020 (in English) 
[3] D. Frezzo, "The role of technology in the education of the future," World Economic Forum, 2020. [Online]. Available: https://www.weforum.org/agenda/2017/05/science-of-learning/ Accessed on: 15.09.2020 (in English)

[4] Schools of the Future: Defining New Models of Education for the Fourth Industrial Revolution, World Economic Forum, 2020. [online] Available: http://www3.weforum.org/docs/WEF_Schools_of_the_Future__Report_2019.pdf. Accessed on: 15.09.2020 (in English)

[5] O. Yu. Burov, "Individual abilities and lifelong learning," Information Technologies and Learning Tools, 5(55), pp.1-11. 2016.https://doi.org/10.33407/ITLT.V55I5.1487. (in English)

[6] O. Orliuk, "Education on intellectual property in the higher education system of Ukraine: problems and tasks," Teoriya i praktika intelektual'noï vlasnosti, 6, pp.148-159, 2019. (in Ukrainian)

[7] A.Pipikaite, and N. Davis, "Why cybersecurity matters more than ever during the coronavirus pandemic," World Economic Forum, 2020. [online] Available: https://www.weforum.org/agenda/2020/03/coronavirus-pandemic-cybersecurity. Accessed on: 15.08.2020 (in English)

[8] The Ultimate List Of Cyber Security Statistics For 2019. PurpleSec LLC. [Online] Available: https://purplesec.us/resources/cyber-security-statistics/ Accessed on: 16.08.2020 (in English)

[9] Beware of criminals pretending to be WHO. World Health Organization, 2020. [Online] Available: https://www.who.int/about/communications/cyber-security/. Accessed on: 16.08.2020 (in English)

[10] Joseph S. Nye, "Technology is driving another global power shift," The Strategist, 7 Aug 2020. [Online] Available: https://www.aspistrategist.org.au/technology-is-driving-another-global-power-shift/. Accessed on: 18.08.2020 (in English)

[11] R. Danzig, "Technology Roulette: Managing Loss of Control as Many Militaries Pursue Technological Superiority," Technology \& National Security, June 2018. [Online] Available: https://s3.amazonaws.com/files.cnas.org/documents/CNASReport-Technology-RouletteDoSproof2v2.pdf?mtime $=20180628072101$. Accessed on: 16.08.2020 (in English)

[12] A. L. Grinin, L. E. Grinin, “ Leading technologies of the sixth technological order,” 2017. [Online] Available:

https://www.researchgate.net/profile/Leonid_Grinin/publication/323996170_VEDUSIE_TEHNOLOGII_ SESTOGO_TEHNOLOGICESKOGO_UKLADA/links/5ab78ea5aca2722b97cea5cc/VEDUSIETEHNOLOGII-SESTOGO-TEHNOLOGICESKOGO-UKLADA.pdf. Accessed on: 16.08 .2020 (in Russian)

[13] Derwent Top 100 Global Innovators ${ }^{\mathrm{TM}}$. Clarivate Analitics Derwent, 2020. [Online]. Available: https://clarivate.com/derwent/top100innovators/ Accessed on: 20.08.2020 (in English)

[14] "New List of Top 100 Innovative Companies in the World." [Online] Available: https://clarivate.ru/blog/2020_02_derwent_top100_innovators. Accessed 20.08.2020 (in Russian)

[15] C. Li, and F. Lalan, "The COVID-19 pandemic has changed education forever. This is how." [Online] Available: https://www.weforum.org/agenda/2020/04/coronavirus-education-global-covid19-onlinedigital-learning. Accessed on: 21.08.2020 (in English)

[16] O. Yu. Burov, "Technology and innovation in human activity of the information age: information challenges and technologies," Information Technologies and Learning Tools, 5 (49), pp.16-25. https://doi.org/10.33407/itlt.v49i5.1274. 2015 (in Ukrainian)

[17] António Guterres, "The future of education is here." Launch of the policy brief: education during COVID-19 and beyond," United Nations. [Online] Available: https://www.un.org/en/coronavirus/futureeducation-here. Accessed on: August 04, 2020 (in English)

[18] A. V. Iatsyshyn, et al., "Application of augmented reality technologies for preparation of specialists of new technological era," Application of augmented reality technologies for preparation of specialists of new technological era, Augmented Reality in Education: Proceedings of the 2nd International Workshop (AREdu 2019), KryvyiRih, Ukraine, March 22, 2019, pp. 181-200. ISSN 1613-0073. [Online] Available: http://ceur-ws.org/Vol-2547/paper14.pdf, 2020 (in English)

[19] O. P. Pinchuk et al., "Digital transformation of learning environment: aspect of cognitive activity of students," In: Proceedings of the 6th Workshop on Cloud Technologies in Education (CTE 2018), KryvyiRih, Ukraine, December 21, 2018 (No. 2433, pp. 90-101). CEUR Workshop Proceedings, 2019 (in English)

[20] Carlos J. Ochoa, "Disruptive Education through Immersive Learning Technologies," VRARA Education Committee. Piacenza (Italy), 24.09.2019. [Online] Available: https://www.thevrara.com/blog2/2019/10/29/disruptive-education-through-immersive-learningtechnologies. Accessed on: 21.08.2020 (in English)

[21] O.Ju. Burov, "Educational Networking: Human View to Cyber Defense," Information Technologies and Learning Tools, 52, pp.144-156. https://doi.org/10.33407/itlt.v52i2.1398.2016 (in English) 
[22] Apple, Google, Samsung, Xiaomi and even Adidas: the most innovative companies in the world are named. 29.06.2020. [Online]. Available: https://ichip.ru/novosti/apple-google-samsung-xiaomi-i-dazheadidas-nazvany-samye-innovacionnye-kompanii-mira-728042. Accessed on: 22.08.2020 (in English)

[23] Z. Yan, T. Robertson, R. Yan, Sung Yong Park, S. Bordoff, Q. Chen, and E. Sprissler, "Finding the weakest links in the weakest link: How well do undergraduate students make cybersecurity judgment?", Computers in Human Behavior, vol. 84, pp. 375-382, 2018 (in English)

[24] R. M. Hernandez, "Impacto de las TIC en la educación: Retos y Perspectivas. Propósitos y Representaciones," 5(1), pp.325 - 347 http://dx.doi.org/10.20511/pyr2017.v5n1.149(2017) Accessed on: 22.08.2020 (in Spanish)

[25] Antonio-José Moreno-Guerrero, et al., "WhatsApp and Google Drive Influence on Pre-service Students' Learning," Front. Educ., 18 August 2020. [Online] Available: https://www.frontiersin.org/articles/10.3389/feduc.2020.00152/full\#B19, 2020 Accessed on: 22.08.2020 (in English)

[26] O. B. Butnik-Siverskyi, "Development of intellectual capital and its components in the aspect of processes of intellectualization, capitalization and transformation (theoretical and methodological digression)." Vseukrainskyi seminar z problem ekonomiky intelektualnoi vlasnosti: zbirnyk naukovykh prats II Vseukrainskoi naukovo-praktychnoi konferentsii (Kyiv, 24 May 2019) NDI intelektualnoi vlasnosti NAPrN Ukrainy. K., pp.9-46 (in Ukrainian)

[27] D. Elliott and L. Quest, "It's Time to Redefine How Data Is Governed, Controlled and Shared. Here's How." [Online] Available: https://www.brinknews.com/its-time-to-redefine-how-data-is-governedcontrolled-and-shared-heres-how/ Accessed on: 22.08.2020 (in English)

[28] H. Androshchuk, "Trends in the development of artificial intelligence technologies: economic and legal aspect," Teoriia I praktyka intelektualnoi vlasnosti, no. 3, pp.84-101, 2019. doi: https://doi.org/10.33731/32019.173817 (in Ukrainian)

[29] K. Horska, "Chapter16. Media content: regulatory challenges in digital environment," Professionalism in journalism in the era of new media, Logos Verlag Berlin GmbH, 2015. (in English)

[30] Yuliya Krylova-Grek, "Psycholinguistic Aspects of Humanitarian Component of Cybersecurity," Psycholinguistics, 26(1), pp.199-215, 2019, doi: 10.31470/2309-1797-2019-26-1-199-215. (in English)

Text of the article was accepted by Editorial Team 13.07.2020

\title{
КІБЕРБЕЗПЕКАТА ІННОВАЦІЙНЕ ЦИФРОВЕ ОСВІТНЕ СЕРЕДОВИЩЕ
}

\author{
Буров Олександр \\ доктор технічних наук, старший дослідник \\ Інститут інформаційних технологій і засобів навчання НАПН України, м. Київ, Україна \\ ORCID ID 0000-0003-0733-1120 \\ ayb@iitlt.gov.ua
}

\author{
Бутнік-Сіверський Олександр \\ доктор економічних наук, \\ професор, академік Академії технологічних наук України, головний науковий співробітник \\ Науково-дослідний інститут інтелектуальної власності НАПрН України, м. Київ, Україна \\ ORCID ID 0000-0003-2492-231X \\ busiv@ukr.net
}

\section{Орлюк Олена}

доктор юридичних наук, професор, академік Національної академії правових наук України, в.о. директора Інституту права Київського національного університету імені Тараса Шевченка, радник при дирекції Науково-дослідного інституту інтелектуальної власності НАПрН України, м. Київ, Україна ORCID ID 0000-0002-5890-6783

e.orliyk@ndiiv.org.ua

\section{Горська Катерина}

доктор наук із соціальних комунікацій

Інститут журналістики Київського національного університету імені Тараса Шевченка, м. Київ, Україна ORCID ID 0000-0002-3430-6206

k_horska@univ.net.ua 


\begin{abstract}
Анотація. У статті розглядається взаємодія інновацій, кібербезпеки та цифрового освітнього середовища. Продемонстровано, що всебічна цифровізація суспільства супроводжується змінами в інноваційному потенціалі та освітніх потребах України, особливо в розвитку інтелектуального капіталу людини та його захисту в цифровому середовищі. Зазначається, що людський капітал в інноваціях відіграє значну роль, особливо в епоху цифрових технологій, інформація стає не лише середовищем, а інструментом діяльності. Молодь розглядається як вразлива група, яка може бути головною метою кібер-когнітивних операцій у довгостроковій перспективі, і як найслабша ланка Системи. Кібербезпека учасників навчального процесу повинна мати такі види захисту, як правовий, технічний, інформаційний, організаційний та психологічний.

Аналіз звіту ВОІВ з Глобального інноваційного індексу (ГІІ) показав, що реальний рівень цифровізації в Україні не відповідає людському потенціалу. Зокрема інфраструктурний складник у цілому та навіть Інформаційно-комунікаційні технології як суб-складник не відповідають вимогам сучасних тенденцій у світі. Україна зіткнулася 3 прогалинами в трикутнику «людський капітал (потенціал) - технологічна підтримка інновацій - творча діяльність», які слід усунути для збільшення національного ГІІ.

Однак слід зазначити, що спільний проєкт, реалізований у цифровій мережі, стає найслабшою ланкою 3 точки зору інтелектуального капіталу та права інтелектуальної власності. Зазвичай особиста інформація про конкурентів проєкту також не захищається. Отже, проблеми інновацій у цифровому навчальному середовищі загострюють питання кібербезпеки учасників навчального процесу. Усе більше і більше фактів вказують на те, що традиційний підхід до кібербезпеки не здатний виявляти та вирішувати нові складні атаки. Автори пропонують загальну модель кібер-загроз у сфері освіти та пом'якшення їх дії. Запропонована нова стратегія в галузі кібербезпеки, яка може бути ефективною: не лише оперативна оборона, але й підготовка користувачів до завчасного виявлення (пошуку) загроз та розвиток життєстійкості. Виявлення загроз може бути представлене двома підходами: виявлення загроз (реактивний) та дослідження загроз (про-активний), що швидко розвивається. Навчання стійкості користувачів пов'язане з обізнаністю про загрози та спеціальним тренінгом з кібербезпеки.

Посилюється роль медіа у стимулюванні горизонтальної комунікації в освітньому процесі. В умовах стрімкого переходу його учасників від пасивного споживання до ролі просьюмера медіа постають у якості інформаційного посередника з подвійною функцією: платформи забезпечення доступу та обміну інформацією учасникам освітнього процесу та технологічного інструментарію для, зокрема, спільного створення продуктів (creative commons, co-creative).
\end{abstract}

Ключові слова: ІКТ; інновації; цифрове інформаційне середовище; медіа; інтелектуальна власність; кібербезпека.

\title{
КИБЕРБЕЗОПАСНОСТЬ И ИННОВАЦИОННАЯ ЦИФРОВАЯ ОБРАЗОВАТЕЛЬНАЯ СРЕДА
}

\author{
Буров Александр \\ доктор техн.ических наук, старший исследователь \\ Институт информационных технологий и средств обучения НАПН Украины, г. Киев, Украина \\ ORCID ID 0000-0003-0733-1120 \\ ayb@iitlt.gov.ua
}

\section{Бутник-Сиверский Александр}

доктор экономических наук, профессор,

академик Академии технологически наук Украины, главный научный сотрудник

Научно-исследовательский институт интеллектуальной собственности НАПрН Украины, г. Киев, Украина

ORCID ID 0000-0003-2492-231X

busiv@ukr.net 


\section{Орлюк Елена}

доктор юридических наук, профессор, академик Нацинальной академии правовых наук Украини, и.о. директора Института права Киевского национального университета имени Тараса Шевченко, советник при дирекции Научно-исследовательского института интеллектуальной собственности НАПрН Украины, г. Киев, Украина

ORCID ID 0000-0002-5890-6783

e.orliyk@ndiiv.org.ua

\section{Горская Екатерина}

доктор наук по социальным коммуникациям

Институт журналистики Киевского национального университета им. Тараса Шевченко, г .Киев, Украина

ORCID ID 0000-0002-3430-6206

k_horska@univ.net.ua

Аннотация. В статье рассматривается взаимодействие инноваций, кибербезопасности и цифровой образовательной среды. Продемонстрировано, что комплексная цифровизация общества сопровождается изменением инновационного потенциала и образовательных потребностей Украины, особенно в развитии человеческого интеллектуального капитала и его защите в цифровой среде. Отмечается, что человеческий капитал в инновациях играет значительную роль, особенно в эпоху цифровых технологий. Молодежь рассматривается как уязвимая группа, которая может быть главной целью кибер-когнитивных операций в долгосрочной перспективе, и как слабое звено Системы.

Анализ отчета ВОИС по Глобальному инновационному индексу (ГИИ) показал, что реальный уровень цифровизации в Украине не соответствует человеческому потенциалу. В частности, инфраструктурная составляющая в целом и даже информационнокоммуникационные технологии как суб-составляющие не соответствуют требованиям современных тенденций в мире. Украина столкнулась с пробелами в треугольнике «человеческий капитал (потенциал) - технологическая поддержка инноваций - творческая деятельность», которые следует устранить для увеличения национального ГИИ.

Однако, следует отметить, что совместный проект, реализованный в цифровой сети, становится слабым звеном с точки зрения интеллектуального капитала и интеллектуальной собственности. Обычно личная информация о конкурентах проекта также не защищается. Таким образом, проблемы инноваций в цифровой учебной среде обостряют вопрос кибербезопасности участников учебного процесса. Все больше и больше фактов указывают на то, что традиционный подход к кибербезопасности не способен выявлять и решать новые сложные атаки. Авторы предлагают общую модель кибер-угроз в сфере образования и смягчения их действия. Предложена новая стратегия в области кибербезопасности, которая может быть эффективной: не только оперативная оборона, но и подготовка пользователей к заблаговременному выявлению угроз и развитие жизнестойкости. Выявление угроз может быть представлено двумя подходами: выявление угроз (реактивный) и исследование угроз (про-активный), который быстро развивается. Обучение устойчивости пользователей связано с осведомленностью об угрозах и специальным тренингом по кибербезопасности.

Усиливается роль медиа в стимулировании горизонтальной коммуникации в образовательном процессе. В условиях стремительного перехода участников от пассивного потребления медиа выступают в роли информационного посредника с двойной функцией: платформы обеспечения доступа и обмена информацией участникам образовательного процесса и технологического инструментария для совместного создания продуктов (creative commons, co-creative).

Ключевые слова: ИКТ; инновации; цифровая информационная среда; СМИ; интеллектуальная собственность; кибербезопасность.

\section{$(\mathrm{Cc}) \mathrm{BY}-\mathrm{NC}-\mathrm{SA}$}

This work is licensed under Creative Commons Attribution-NonCommercial-ShareAlike 4.0 International License. 